Editorial comment

\title{
Polymorphism in the $\mu$-opioid receptor gene OPRM1 A118G-An example of the enigma of genetic variability behind chronic pain syndromes
}

\author{
Pål Klepstad ${ }^{\mathrm{a}, \mathrm{b}, *}$ \\ a Department of Circulation and Medical Imaging, Faculty of Medicine, Norwegian University of Science and Technology (NTNU), Trondheim, Norway \\ ${ }^{\mathrm{b}}$ St. Olavs Hospital, Department of Anaesthesiology and Intensive Care Medicine, Trondheim, Norway
}

In this number of the Scandinavian Journal of Pain, Ulrika Heddini et al. [1] observed that single nucleotide polymorphism (SNP) variability in the OPRM1 A118G (rs1799971) was related to chronic pain from vestibulodynia. The same A-allele in the OPRM1 A118G that increased risk for vestibulodynia was also related to higher experimental pain sensitivity. Women with vestibulodynia also had higher levels of plasma concentrations of the endogenous opioid beta-endorphin. Thus, in this study the evidence suggest that the $G$ allele should protect against this sort of chronic pain.

\section{OPRM1 A118G in experimental studies}

The influence from genetic variability on pain perception and opioid efficacy is not to be disputed. Common clinical experience is that patients vary, and state of the art twin studies have demonstrated the inheritability of both pain perception and opioid efficacy [2,3]. Obviously, the gene coding for the OPRM1 receptor is one of the candidate genes for pain and opioid efficacy. The most studied of the 43 SNPs identified by Hoehe et al. within the OPRM1 gene is the OPRM1 A118G [4]. This SNP altered experimental effects from beta-endorphin [5], and early human experimental studies by Lötsch et al. [6] showed that subjects carrying one or two copies of the variant $118 \mathrm{G}$ allele had decreased pupillary constriction after M6G administration. Variability in OPRM1 A118G influences cortical activation after nocioceptive stimuli [7], and an example of some of the further evidence for the effect of $\mathrm{A} 118 \mathrm{G}$ polymorphisms were supplied by Romberg et al. who showed that patients with the variant allele needed about threefold M6G serum concentration in order to increase the threshold to painful electric stimulation [8].

\section{OPRM1 A118G in clinical studies}

Findings in experimental studies must be confirmed in clinical studies in order to establish the clinical significance of biological

DOI of refers to article: http://dx.doi.org/10.1016/j.sjpain.2013.10.004.

* Corresponding author at: Department of Intensive Care Medicine, 7006 Trondheim, Norway. Tel.: +47 72575709 .

E-mail address: pal.klepstad@ntnu.no variability. In a study including 100 cancer patients the OPRM1 A118G polymorphism changed the need of morphine doses to achieve adequate pain relief from cancer pain. Patients homozygous needed about twice the morphine doses needed by wild type patients in order to achieve adequate pain relief. This difference was also reflected in serum concentrations of morphine and M6G [9]. Similar results were observed by Campa et al. who assessed pain relief achieved after start of morphine to cancer pain patients [10], and in several studies of opioid efficacy for postoperative pain $[11,12]$. These and other studies established a firm belief that this SNP was an important predictor for clinical opioid efficacy. However, a meta-analysis by Walter and Lötsch et al. [13] failed to confirm this finding, and in the first large scale study assessing genetic variability and opioid doses for cancer pain Klepstad et al. did not observe any effects from the OPRM1 A118G [14]. Also, studies in labour pain showed an effect from the OPRM1 A118G, but surprisingly in the other direction as for other studies [15]. Therefore, in spite of many studies convincingly pointing at an association between genetic variability in the gene coding the mu-opioid receptor and opioid effects, these observations are not confirmed in meta-analyses or large scale studies.

\section{Why such conflicting results?}

The paper by Heddini et al. [1] is a typical paper in this field of research. The study is well performed but has a limited number of patients; it studies only one gene, and has no validation sample. Therefore, this finding has a high risk of ending in the $96 \%$ of positive genetic findings not replicated in later studies. The use of larger samples and to demonstrate that results are replicated in other populations will result in more robust findings. Such studies are of course by several factors more complicated and expensive to perform. Therefore, also the small-scale small studies are needed in order to generate hypotheses to be tested in more conclusive studies.

Another reason that small studies involving only one or a few SNPs may not be consistent in their finding is that genetic variability is more complex. First, genes may interact $[10,16]$. Second, candidate gene studies only include genes believed to influence the 
outcome. Preliminary genome wide association studies for clinical pain and opioid efficacy suggest that genetic variability in other than the usually studied pathways are of some importance [17]. Third, genetic variability in the OPRM1 gene can be caused by other mechanism than SNPs. Animal studies have identified that variability in selection of exon regions during translation to mRNA give multiple OPRM1 receptor variants (splice variants) that may be responsible for varying analgesic response and adverse effects from morphine and M6G [18]. OPRM1 receptor splice variants are also present in the human brain [19], and may explain some of the relevant clinically observed differences. Finally, the result of genetic variability can be the result of interplay between genetic and environmental factors.

\section{What now?}

The current situation for genetic variability in the OPRM1 A118G SNP can, as for other genes, be summarized like this: evidence certainly shows that such variability is relevant for clinical effects, but that the clinical importance is not established and that the biological mechanisms show a complexity beyond our current understanding. The combination of clinical relevance and lack of knowledge of course points towards the perhaps overused but still true expression, "More research is needed".

\section{Conflicts of interest}

No conflicts of interest declared.

\section{References}

[1] Heddini U, Johannesson U, Grönbladh A, Nyberg F, Nilsson KW, Bohm-Starke N. A118G polymorphism in the $\mu$-opioid receptor gene and levels of $\beta$-endorphin are associate with provoked vestilbulodynia and pressure pain sensitivity. Scand J Pain 2014;5:10-6.

[2] Angst MS, Phillips NG, Drover DR, Tingle M, Ray A, Swan GE, Lazzeroni LC, Clark JD. Pain sensitivity and opioid analgesia: a pharmacogenomic twin study. Pain 2012;153:1397-409.

[3] Angst MS, Lazzeroni LC, Phillips NG, Drover DR, Tingle M, Ray A, Swan GE, Clark JD. Aversive and reinforcing opioid effects: a pharmacogenomic twin study. Anesthesiology 2012;117:22-37.

[4] Hoehe MR, Köpke K, Wendel B, Rohde K, Flachmeier C, Kidd KK, Berrettini $\mathrm{WH}$, Church GM. Sequence variability and candidate gene analysis in complex disease: association of $\mu$-opioid receptor gene variation with substance dependence. Hum Mol Genet 2000;9:2895-908.
[5] Bond C, LaForge KS, Tian M, Melia D, Zhang S, Borg L, Gong J, Schluger J, Strong JA, Leal SM, Tischfield JA, Kreek MJ, Yu L. Single-nucleotide polymorphism in the human mu opoid receptor gene alters beta-endorphin binding and activity: possible implications for opiate addiction. Proc Natl Acad Sci 1998;95: 9608-13.

[6] Lotsch J, Geisslinger G. Current evidence for a genetic modulation of the response to analgesics. Pain 2006;121:1-5.

[7] Lotsch J, Stuck B, Hummel T. The human $\mu$-opioid receptor gene polymorphism 118A $>$ G decreases cortical activation in response to specific nociceptive stimuli. Behav Neurosci 2006;120:1218-24.

[8] Romberg R, Olufsen E, Bijl H, Romberg R, Olufsen E, Bijl H. Polymorphism of $\mu$-opioid receptor gene (OPRM1:c.118A $>\mathrm{G}$ ) does not protect against opioid-induced respiratory depression despite reduced analgesic response. Anesthesiology 2005;102:522-30.

[9] Klepstad P, Rakvåg TT, Kaasa S, Holthe M, Dale O, Borchgrevink PC, Baar C, Vikan T, Krokan HE, Skorpen F. The $118 \mathrm{~A}>\mathrm{G}$ polymorphism in the human $\mu$-opioid receptor gene may increase morphine requirements in patients with pain caused by malignant disease. Acta Anaesthesiol Scand 2004;48: 1232-9.

[10] Campa D, Gioia A, Tomei A, Poli P, Barale R. Association of ABCB1/MDR1 and OPRM1 gene polymorphisms with morphine pain relief. Clin Pharmacol Ther 2008;83:559-66

[11] Chou WY, Yang LC, Lu HF, Wang CH, Lin SH, Lee TH, Concejero A, Hsu CJ. Association of mu opioid receptor gene polymorphism (A118G) with variations in morphine consumption for analgesia after total knee arthoplasties. Acta Anaesthesiol Scand 2006;50:787-92.

[12] Chou WY, Wang CH, Liu P-H, Liu C-C, Tseng CC, Jawan B. Human opoid receptor A118G polymorphisms affects intravenous patient-controlled analgesia morphine consumption after total abdominal hysterectomia. Anesthesiology 2006;105:334-7.

[13] Walter C, Lötsch J. Meta-analysis of the relevance of the OPRM1 118A>G genetic variant for pain treatment. Pain 2009;146:270-5.

[14] Klepstad P, Fladvad T, Skorpen F, Bjordal K, Caraceni A, Dale O, Davies A, Kloke M, Lundström S, Maltoni M, Radbruch L, Sabatowski R, Sigurdardottir V, Strasser F, Fayers PM, Kaasa S, European Palliative Care Research Collaborative (EPCRC), European Association for Palliative Care Research Network. Influence from genetic variability on opioid use for cancer pain: a European genetic association study of 2294 cancer pain patients. Pain 2011;152:1139-45.

[15] Sia AT, Lim Y, Lim EC, Goh RW, Law HY, Landau R, Teo YY, Tan EC. A118G single nucelotide polymorphism of human mu-opioid receptor gene influences pain perception and patient-controlled intravenous morphine consumption after intrathecal morphine for postoperative analgesia. Anesthesiology 2008;109:520-6.

[16] Reyes-Gibby CC, Shete S, Rakvåg T, Bhat SV, Skorpen F, Bruera E, Kaasa S, Klepstad P. Exploring joint effects of genes and the clinical efficacy of morphine for cancer pain: OPRM1 and COMT gene. Pain 2007;130:25-30.

[17] Galvan A, Skorpen F, Klepstad P, Knudsen AK, Fladvad T, Falvella FS, Pigni A, Brunelli C, Caraceni A, Kaasa S, Dragani TA. Multiple loci modulate opioid therapy response for cancer pain. Clin Cancer Res 2011;17:4581-7.

[18] Pasternak GW. Incomplete cross tolerance and multiple mu opioid peptide receptors. Trends Pharmacol Sci 2001;22:67-70.

[19] Pan YX, Xu J, Mahurter L, Xu M, Gilbert AK, Pasternak GW. Identification and characterization of two human mu opioid receptor splice variants, hMOR-10 and hMOR-1X. Biochem Biophys Res Commun 2003;301:1057-61. 